\title{
USA's præsidentvalg: slaget om konservatismens sjæl
}

\section{Annegrethe Rasmussen}

\section{Den republikanske bevægelse er dybt splittet mel- lem en moderat ledelse og en uregerlig højrepo- pulistisk base i Tea Party-bevægelsen. De konserva- tive aktivister mistror favoritten, Mitt Romney, men deres foretrukne kandidater kan nok ikke vinde i 2012}

Kan Republikanerne vinde det amerikanske præsidentvalg i 2012?

Det er et spørgsmål, som indtil midtvejsvalget i 2010 syntes nærmest teoretisk. Valgforskere og sociologer verden over stod i kø efter Barack Obamas valgsejr i 2008 med analyser af, hvorfor den demografiske udvikling i USA ville gavne Demokraterne fremover (et hastigt voksende antal af både sorte vælgere og vælgere med latinamerikanske rødder, der traditionelt har stemt på Demokraterne). Samtidig var der en global beundring for den velsagtens mest teknologisk avancerede valgkampagne verden havde set til dato, hvor Obama kødeliggjorde det moderne ved at lede en valgkamp med de sociale medier i førersædet. John McCain virkede til gengæld både gammel og gammeldags, rodfæstet i en anden tid som Vietnam-veteran og latterliggjort som manden, der ikke selv sendte sine e-mails.

Republikanerne syntes dømt til en lang ørkenvandring. Mange analytikere drog sammenligninger med de britiske konservative, der i lyset af New Labour og Tony Blairs succeser måtte igennem over 10 års pinefuld moderniseringsproces på oppositionsbænkene for at blive valgbare igen.

I dag er størstedelen af disse analyser gjort til skamme. Godt nok er der fortsat 11 måneder til det amerikanske præsidentvalg, men det står lysende klart: Republikanerne er tilbage; de er fulde af selvtillid efter sejren ved midtvejsvalget i 2010 og de har gode opinionsmålinger i ryg- 
gen. Og de har på ingen måde været igennem en proces, der har bragt dem nærmere på midten eller på Demokraterne. Sammenligningen med de britiske toryer viser endnu engang, at det er futilt, og ofte decideret vildledende at drage sammenligninger mellem de europæiske politiske systemer og USA.

Et særegent karakteristikum for USA er fx, at man som politiker kan fyre op under sin egen base op til primærvalgene. Det finder man ikke på tilsvarende vis i Danmark, hvor det betyder mindre at tabe på fløjene, fordi vælgerne ikke skifter blok - når S fx stemmefisker til højre, flytter de frustrerede venstreorienterede vælgere blot over til SF og Enhedslisten. Sådan spiller klaveret ikke i USA. Mister man sin base, vandrer den mod sofaen. Og så taber man valget. Stemmeprocenten er også langt lavere, og derfor er det lille mindretal af partiaktivister helt afgørende.

Med Tea Party-bevægelsens folkelige gennembrud i 2009 er det evident, at basen er rykket kraftigt til højre. Partiet er rykket med, og den eneste proces de har været igennem efter nederlaget til Barack Obama i 2008, er en radikalisering mod højre.

Heroverfor står Obama, hvis popularitet ligger nede omkring de 40 pct., og som nu har en ægte risiko for at ende som en 'one term president'. Det, der i 2008 syntes at være en umulighed, er sket: Republikanerne er tilbage, og de har især vun- det terræn blandt de hvide vælgere, mest blandt de dårligere uddannede. Hertil skal man i øvrigt lægge en omlægning af valgdistrikter og ny vægtning af staterne i lyset af folketællingen i 2010, der reducerer de såkaldte blå staters (altså de demokratiske) vægt i valgmandskollegiet.

\section{Omfattende politikerlede i USA}

Det første varsel om de nye tider kom ved midtvejsvalget. Mange hundredetusinde demokratiske vælgere (især blandt sorte og yngre vælgere) der havde stemt for første gang i 2008, valgte at blive hjemme på sofaen. Dels fordi det var midtvejsvalg, hvor valgdeltagelsen altid er signifikant lavere end ved præsidentvalget, dels fordi den midtsøgende og pragmatiske præsident havde skuffet store dele af sin nye base. I tørre tal stemte omkring 131 millioner mennesker i 2008, mens blot 87 millioner forføjede sig til stemmeurnerne i 2010.

Hvis det gentager sig i 2012, vil det være dødeligt for Obamas valgchancer, mens omvendt Tea Partybevægelsens opildnede masser vil gavne Republikanerne, nøjagtigt som det skete ved midtvejsvalget.

Der er imidlertid intet nyt i, at vælgerne straffer det regerende parti og præsidenten i strenge tider som de nuværende, hvor den økonomiske recession har bidt sig fast, og arbejdsløshedstallet på omkring 9-10 pct. (reelt tættere på 16) heller 
ikke viger ud af stedet. Ansvaret havner altid i Det Hvide Hus.

Ikke desto mindre vil det være præmaturt at dømme republikanerne endeligt inde og Obama ude. For det første viser meningsmålingerne, at amerikanerne i stigende grad er dybt utilfredse med hele det politiske system, og det inkluderer Republikanerne og især den samlede Kongres, hvis popularitet svinger mellem 15 og 20 pct.. For det andet svinger målingerne. Præsidenten har rigtig nok ligget langt nede $\mathrm{i}$ målingerne, omkring 40 pct., men i starten af november tog tallene et hop opad til tæt på 50 .

Det største problem for Republikanerne er imidlertid ikke præsident Obama, hvis svagheder på især indenrigspolitikken er åbenlyse. Det største problem er internt: partiet har været ude af stand til at finde et udvalg af kandidater, der kan favne over den velkendte splittelse i partiet mellem moderate og yderligtgående konservative.

\section{Kandidaterne}

Pt. består feltet af følgende, seriøse, kandidater, og ingen regner med at nye melder sig:

- Rick Santorum, advokat og tidligere medlem af Senatet for Pennsylvania. Santorum er højrekonservativ på såvel fiskale som sociale områder.

- Newt Gingrich, tidligere formand for Repræsentanternes Hus fra 1995-99. I dag politisk analytiker og grundlægger af flere tænketanke herunder 'American Solutions for Winning the Future.'

- Michele Bachmann, medlem af Repræsentanternes Hus for Minnesota siden 2007. Ud over at være erklæret talsmand for Tea Party-bevægelsen i Kongressen og aktiv kristen, er Michele Bachmann bemærkelsesværdig ved at være mor/fostermor til 23 børn, heraf syv hjemmelavede.

Ron Paul, medlem af Repræsentanternes Hus for Texas og feltets ældste kandidat, 76 år, og kendt som en særdeles principiel libertarianer. Han ønsker fx det meste af den statslige administration nedlagt og en komplet fri våbenlovgivning. Han er også modstander af militær intervention i andre lande, således var han modstander af det amerikanske militære engagement i Irak.

Jon Huntsman er diplomat og tidligere guvernør for Utah. Han er den mest moderate i feltet af kandidater, mormon og far til ni. Før opstillingen var han USA's ambassadør i Kina. Han taler flydende mandarin.

Mitt Romney har prøvet turen før. Den rutinerede forretningsmand og politiker er tidligere guvernør for den liberale stat Massachusetts og tabte i 2008 nomineringen for Republikanerne til John McCain. Han positioneres som den mest midts $\varnothing$ gende kandidat, men trækkes med et image som en 'flip-flopper', der har skiftet holdninger for at tækkes forskellige vælgergrupper. Han er også mormon. 
Rick Perry er guvernør for Texas. Han var i ugevis højrefløjens absolutte favorit. Han er en formidabel pengemaskine og han kan bryste sig af, at Texas har rekorden i jobskabelse i det arbejdsløshedsramte USA. Men han har forskertset sin position som outsider og favorit på 'alt-andet-end- Romney-holdet' ved dels at have en mere rummelig indvandrerpolitik end den, højrefløjen i partiet står for, dels ved ikke at kunne deltage i offentlige debatter uden at dumme sig konstant. Hans usammenhængende tale, grimasser og pinlige forsøg på upassende vittigheder har ført til seriøse diskussioner om, hvorvidt han har et pillemisbrug eller alkoholproblem.

Herman Cain var i hele oktober 2011 på en formidabel optur. Den veltalende tidligere administrerende direktør for fastfood-kæden 'Godfather's Pizza' og tidligere chef for den amerikanske forening af restauratører er en fremragende taler med bunker af humoristisk sans. Han tilhører højrefløjen i partiet, men manglende viden om verden uden for USA, manglende politisk erfaring og anklager om sexchikane fra en række tidligere ansatte fik hans popularitet til at dykke i starten af november. Han er den eneste afroamerikaner i feltet.

De fleste amerikanske politiske kommentatorer er sikre på, at Paul, Bachmann og Huntsman reelt er ude af spillet. Til gengæld er det åbent, hvad der vil ske, når primær- valgene starter i første uge af januar 2012 med Iowa i front. De fluktuerende meningsmålinger viser kun en ting: at Mitt Romneys konstante opbakning på lige under 25 pct. ikke er nok til at være sikker på nomineringen. Til gengæld skifter det fra måned til måned hvem der er øjeblikkets anti-Romney kandidat.

\section{Historisk splittelse}

Hvad slaget ender med, ved ingen, men den iltre, konservative Tea Party-bevægelse nærer under alle omstændigheder en indgroet skepsis over for selve jobbet som politiker. Vinder en 'partiapparatjik', er der risiko for, at disse vælgere som nævnt før, vælger slet ikke at stemme. Samtidig kræver de højrelibertære kræfter dramatiske beskæringer af de ellers populære offentlige hjælpeprogrammer, Social Security, Medicaid og Medicare, i en kombination med markante skattelettelser. En særdeles risikabel strategi.

I den gruppe står alle andre kandidater end Romney og Jon Huntsman. Sidstnævnte repræsenterer den pt. nærmest forsvundne republikanske venstrefløj. Alene Huntsmans beskedne udsagn om, at han tror klimaforandringerne har en 'menneskelig komponent,' og så det faktum at han har været præsident Obamas ambassadør i Kina, gør ham internt uvalgbar, og han har på intet tidspunkt været over 6 pct. i de interne meningsmålinger. 
Den pressede moderate fløj frygter at en for højrepopulistisk kandidat vil afskrække de afgørende uafhængige vælgere.

Splittelsen er langt fra ny. Den moderate analyse kaldes også af og til 'the Ronald Reagan approach' med inspiration fra den konservative præsident af samme navn: en filosofi om 'det store telt', hvor både amerikanske socialkonservative (det som vi Danmark ville kalde værdikonservative) og de midtersøgende, fiskale konservative dele af partiet kan samles under en altfavnende fane. Tanken er, at en sådan bred tilgang vil kunne samle de mange frustrerede middelklassevælgere op, som føler sig svigtet af Obama.

Baggrunden for analysen er, at præsident Obama står i modsætning til begge de to førnæunte typer af konservative. De fiskalt konservative kritiserer præsidentens økonomiske politik for ikke at have fået bugt med underskuddet, for ikke at have skabt job og for ikke at have skåret kraftigt nok i de føderale budgetter, samtidig med at der er hældt penge ned i en 'stimuluskloak' uden det $\varnothing n s k e d e$ resultat. De værdikonservative ser en præsident, der hylder en socialliberal dagsorden med støtte til fagforeninger, homoseksuelle, ret til abort, kontrol af våben og støtte til græsrødder, som det nydannede Occupy Wall Street, en voksende græsrodsbevægelse, som Demokraterne forsigtigt har omfavnet i håbet om at få tilført en dosis folkelig energi, der kan motivere en lunken base og kanalisere den dybe folkelige frustration over økonomien over i den demokratiske lejr med et bredt angreb på finansverdenens grådige excesser.

Republikanerne ser omvendt den samme bevægelse som en bunke hippier med hang til bongotrommer, ring i næsen og en uamerikansk tendens til klynkeri og angreb på de frie markedskræfter.

Det er fristende at konkludere, at der blot er én republikansk kandidat, der profiterer af styrkeprøven mellem resten af kandidaterne om Tea Party-vælgerne: favoritten Mitt Romney.

Men Romney kan relativt nemt tabe nomineringen. På trods af at han ses som vidende, solid og kompetent, er han alvorligt tynget af sin egen fortid på to fronter. For det første førte han i sin tid som guvernør for Massachusetts en langt mere liberal politik end den, partiets nuværende profil tilskriver, særligt med indførelsen af universel sygesikring i staten; For det andet tabte han sit partis nominering i 2008 til John McCain. Resultatet er den lidt trætte profil: velkendt, men træt.

\section{Forskelle i økonomisk politik}

På trods af infight er kandidaterne dog enige på flere områder. De vil alle trække præsident Obamas sundhedsreform tilbage. Ingen er tilhængere af fri abort og alle vil sætte skat- 
terne ned og beskære de offentlige udgifter i varierende omfang. Herudover er der stærkt divergerende holdninger til den økonomiske politik, som alle forventer vil forblive i centrum valgkampen igennem.

Forslagene fra kandidaterne spænder vidt - fra et detaljeret lovkatalog på 59 punkter, som Mitt Romney har fremlagt, og som de fleste uafhængige økonomer mener stort set uhindret i teorien kan omsættes til lovgivning, over til Herman Cains besnærende enkle 9-9-9 plan, der foreslår en afskaffelse af den nuværende komplicerede skattelovgivning til fordel for et system med 9 pct. indkomstskat, 9 pct. selskabsskat og 9 pct. moms på nye produkter.

I Cains verden afskaffer staten al skat på kapitalgevinster, transaktioner $\mathrm{og}$ formue og moms på brugte varer. Planen har ikke fået milde ord med på vejen af økonomer. Den begunstiger i ekstrem grad de mest velhavende amerikanere, som i forvejen har fået forbedret deres vilkår betydeligt under Bush.

En tredje plan blev fremlagt af Rick Perry i slutningen af oktober 2011. Forslagets kerne er også et fladt skatteloft, men på 20 pct. på både personskatten og selskabsskatten, der i dag ligger på 35 pct. Perry ønsker også at afskaffe al skat på udbytte og kapitalgevinster. Han vil derudover skære dybt i de føderale udgifter og - mest kontroversielt etablere et system af individuelle, private pensionsopsparinger i direk- te konkurrence med Social Security, der i dag udgør et universelt, offentligt støttet sikkerhedsnet under bl.a. pensionisterne.

Newt Gingrich' plan minder om Perrys, blot ønsker han sig et fladt loft på 15 pct. Michele Bachmann går også ind for en flad skat, men i skrivende stund har hun endnu ikke fremlagt et egentligt forslag.

Den eneste erklærede midter-konservative kandidat, Jon Huntsman, er også alene med sit forslag om at eliminere en lang række eksisterende skattehuller og fradragsmuligheder, samtidig med at han vil indbygge en vis, begrænset progressivitet i en ny skattelov med en tretrins skala bestående af tre satser på henholdsvis 8,14 og 23 pct. Forslaget er dog ikke mere moderat end at det fortsat vil begunstige de bedst stillede.

Den mest radikale i feltet til højre er den libertære kandidat Ron Paul, der stort set vil afskaffe den føderale regering og lukke de fleste offentlige instanser. Institutioner som skatteministeriet, undervisningsministeriet, miljøkontrollen samt en række sociale og kulturelle ordninger skal helt fjernes, og den føderale indkomstskat skal simpelthen ophøre. Paul mener ikke, at den føderale regering har ret til at opkræve skat. Han fortolker den amerikanske forfatning sådan, at den ret udelukkende tilfalder de enkelte stater. Han går dog ind for visse punktskatter og begrænsede afgifter bl.a. for at finansiere militæret. 
Heroverfor ser Mitt Romneys 59punktplan fredelig ud. Her er ingen flade skattelofter den enkle grund, at enhver tale om en flad skat vil resultere i nye, betydelige skattelettelser til de allerrigeste. At sætte de rigestes skatter yderligere ned, vil være kontraproduktivt i et valgår, eftersom meningsmålinger viser, at de amerikanske vælgere i overvældende grad er tilhængere af skatteforhøjelser til de allerrigeste.

Romney har selv argumenteret imod en flad skat med begrundelsen at "princippet om end sympatisk i sit sigte, er urealistisk og ikke gennemførligt." Favorittens 160 sider lange forslag advokerer overordnet en langt mere forsigtig tilgang til reformer end Tea Party-kandidaternes plus en mere aggressiv tilgang til Kina, der trues med sanktioner, hvis ikke kineserne revaluerer deres valuta. Romney ønsker at sætte selskabsskatten ned til 25 pct. Han ønsker også at afskaffe enhver skat på renteindtægter, kapitalgevinster og dividender, men kun for de amerikanere, som tjener under 200.000 dollar om året.

\section{Statsmand eller elitær og indspist?}

Forskellen til de andre kandidater illustrerer Romney-kampagnens strategi. Deres kandidat er nok konservativ, men han er også solid, statsmandsagtig, urokkelig og rolig i sin konservatisme. Med andre ord hævet over umodne fløjkampe og de ekstreme randkandidater, som den erfarne kandidat har benævnt dem.

Strategien har for så vidt båret frugt: Romney er den af de republikanske kandidater, som flest uafhængige vælgere er tiltrukket af. Men samtidig er det netop den glatte og slebne stil, den erfarne politiker, der ikke kan tænde aktivisterne i partiets base. Som er led og ked af 'eliten', 'Washington' og 'the establishment'. Derfor er Romneys styrke samtidig hans akilleshæl. Det som hans tilhængere ser som en præsidentiel aura, ser hans kritikere som kedsommeligt og forudsigeligt.

Et af de primærvalgenes helt store spørgsmål bliver, om den tidligere guvernør kan komme over det skisma og tilføre sin kendte stil noget begejstring. Noget kan eventuelt leveres af en mere farverig vicepræsidentkandidat, uden at det dog vil medføre, at Romney vælger en lige så farverig populistisk kandidat som Sarah Palin var. I den republikanske partiledelse i Washington er analysen fortsat, at valget af Palin var den tungeste udslagsgivende faktor på minussiden i det republikanske nederlag ved sidste præsidentvalg.

\section{Republikanernes udenrigspolitik}

Sluttelig er det interessant at se på eventuelle divergenser mellem kandidaterne på det udenrigspolitiske felt. Uagtet at udenrigspolitik mildest talt har været fraværende ved debatterne op til 2012, forventer det 
patriotisk stolte USA, at deres præsident på en vidende og vægtig måde kan udfylde rollen som verdens mest magtfulde mand. Landets udenrigspolitiske og sikkerhedspolitiske magt gør, at præsidenten altid skal være overbevisende som 'Commander in Chief' for verdens dyreste og stærkeste militær.

På det republikanske kandidathold er forvirringen imidlertid betragtelig. Først og fremmest findes der ingen klar linje i gruppen af Tea Party-sympatiserende kandidater. Ron Paul står for en nærmest isolationistisk linje, hvilket gør ham uegnet til præsidentembedet i størstedelen af sit eget parti.

Herman Cain har nærmest pralet med sin uvidenhed: "Når man spørger mig, hvem der er præsident i Ubeki-beki-beki-beki-stan-stan, ja så vil jeg sige, you know, at det ved jeg ikke - og så vil jeg spørge: 'hvordan skaber det et eneste nyt job."

I de hidtil afholdte debatrunder mellem kandidaterne har udenrigspolitikken været stort set fraværende, hvis man undtager en vag enighed om at 'vi skal slå kineserne', og at man helst ikke vil have flere immigranter ind fra Mexico. Når det gælder Libyen er signalerne vildt modsatrettede. Flere af kandidaterne synes at mene, at USA skulle have gjort 'mere' og 'vist lederskab' - en traditionel republikansk kritik af Obama. Men Michele Bachmann mener omvendt, at Amerika skulle have holdt sig helt udenfor. Newt
Gingrich har præsteret at mene begge ting på samme tid.

Ingen af de republikanske kandidater har ytret sig om Yemen eller om de problemer, der opstår, når USA begynder at dræbe amerikanske statsborgere med ubemandede droner som i tilfældet med terroristen Anwar al-Awlaki og dennes søn. Ingen af kandidaterne - bortset fra Ron Paul - har ofret nogen tankekraft på de moralske eller mulige retlige konsekvenser af at henrette individer med droner uden for ens eget territorium. Om begivenhederne i Syrien er der også tavshed over hele linjen.

Den eneste, der har vist en vedvarende interesse i udenrigspolitikken er Huntsman - hvilket ikke er så underligt, når han nu har været sit lands ambassadør. Men desuagtet har hans interesse virket overfladisk, og han har ikke kunnet engagere nogle af sine partikammerater i en egentlig debat. Huntsmans position er dog mere internationalistisk.

Endelig anlægger Romney en solid, velkendt partilinje tæt på Bush den Yngres. Den tidligere guvernør har hyret en stribe udenrigspolitiske rådgivere til sin kampagne, som har rødder netop i Bush-administrationen med navne som tidligere CIAdirektør Mike Hayden og tidligere minister for Homeland Security Michael Chertoff i spidsen.

Den dominerende tendens i det republikanske parti som sådan bunder fortsat i den realistiske skole in- 
den for international politik. Den er 'Jacksonian' - troen på et stærkt militær der skal bruges aktivt for at forsvare amerikanske interesser i hele verden. Der eksisterer en vis skepsis over hele linjen over for internationale institutioner og diplomati eller idealistiske mål som fx verden som atomvåbenfri (som Obama i princippet har tilsluttet sig) og menneskerettighedstiltag. Verden ses principielt som et farligt og ofte fjendtligt sted, og man er mere skeptisk end Demokraterne over for forhandlede løsninger.

I stedet foretrækkes klare sejre og markeringer, hvilket tydeligt kom til udtryk i den nærmest unisone hån, som Obama måtte stå mål for, da udtrykket 'leading from behind' vandt fremme i den amerikanske debat om taktikken i Libyen. Uanset at man i dag med en vis ret kan sige at denne tilgang netop har taget stik hjem med udviklingen i Libyen.

\section{En helt afgørende slagmark}

Den største test på det udenrigspolitiske felt er og bliver dog konflikten i Afghanistan. Obama står i den ubekvemme situation, at støtten til den amerikanske militære aktion fortrinsvis kommer fra hans modstandere, mens stort set hele den demo- kratiske base blot vil have de amerikanske soldater hjem så hurtigt som muligt. Men igen - som i reformpolitikken over for den arabiske verden og strategien over for såvel Pakistan som Iran - savner kandidaterne at udvikle en klar strategi, der både kan distancere sig fra Obamas og pege på vejen frem.

Det er evident, at grunden til det manglende fokus er, at alle kandidaterne mener, at hele slaget skal vindes på den hjemlige økonomis bane. Heroverfor kan man indvende, at nøjagtigt som den amerikanske finanssektors kollaps har haft alvorlige konsekvenser for og hænger sammen med, hvad der sker i resten af verden, så er også den hjemlige amerikanske økonomi bundet op på et internationalt sundt marked, hvor krige og konflikter ikke hærger.

Udviklingen i eurozonen er mindst lige så vigtig for de amerikanske vælgeres langsigtede velstand som det hjemlige boligmarkeds sundhedstilstand. Det vil sandsynligvis også gå op for kandidaterne hen ad vejen - om ikke andet vil vælgerne kere sig om svaret

Annegrethe Rasmussen har varet Dagbladet Informations korrespondent $i$ Washington DC siden 2008. 